\title{
LAS CLÁUSULAS NOTWITHSTANDING Y OVERRIDE DEL CONSTITUCIONALISMO CANADIENSE
}

\author{
FEDERICO DE MONTALVO JÄÄSKELÄINEN \\ Profesor Propio Adjunto Derecho constitucional \\ (ICADE), UPComillas
}

SUMARIO

I. A modo de introducción: el paradigma de la constitución como norma de precompromiso o autorrestricción

II. ¿Vuelta a la primacía del parlamento o diálogo entre los poderes mayoritario y contramayoritario?

III. Las cláusulas notwithstanding y override del constitucionalismo canadiense

IV. Origen y fundamento de las cláusulas

V. Su virtualidad y futuro en el constitucionalismo canadiense. Análisis de casos

VI. ¿Qué puede enseñarnos la experiencia canadiense?

VII. Conclusiones

\section{A MODO DE INTRODUCCIÓN: EL PARADIGMA DE LA CONSTITUCIÓN COMO NORMA DE PRECOMPROMISO O AUTORRESTRICCIÓN}

Hace ya unos años el noruego Jon Elster publicaba su trabajo titulado Ulises desatado. Estudios sobre racionalidad, precompromiso y restricciones, en el que abordaba, entre otras cuestiones más generales y no esencialmente jurídicas, el concepto de Constitución como precompromiso o autorestricción ${ }^{1}$.

1 ELSTER, J., Ulises desatado. Estudios sobre racionalidad, precompromiso y restricciones, Gedisa, Barcelona, 2002, págs. 111 y ss. El título original sería Ulises unbound. Studies in rationality, precommintment and constraints, Cambridge University Press, Cambridge, 2000, 88 y ss. 
Para Elster lo que se muestra interesante del constitucionalismo que ha imperado en nuestras actuales democracias es que la propia democracia encarnada en el principio de mayoría se sujeta a sí misma, se autorrestringe, con la Constitución, limitando sus decisiones futuras. La Constitución vendría a actuar en nuestras actuales sociedades como instrumento de autoconstricción o autorestricción.

Por ello, Elster se pregunta por qué una asamblea política querría abdicar de la plena soberanía, que posee en principio, y fijar límites a sus propias acciones futuras. Su respuesta se vendrá a fundamentar en la necesidad que tenemos los propios ciudadanos de protegernos contra nuestra propia tendencia a actuar irreflexivamente, llevados por la pasión. Mediante la elevación del costo de la toma de decisión y fundamentalmente de la reforma de la Constitución se dificulta que los ciudadanos cedamos a nuestra propensión temporal a abdicar de nuestros valores esenciales de convivencia consagrados en el texto constitucional. Si todas las instituciones están disponibles, quienes ejerzan el poder se verán tentados de aprovechar sus puestos con fines priva$\operatorname{dos}^{2}$.

Elster recurre, así, a la fábula de Ulises y las sirenas para desarrollar su idea de que en las modernas democracias, la Constitución actúa como norma de autoconstricción. Señala Elster que, tras comprobar que nosotros podemos ser nuestro peor enemigo, procuramos atarnos a través de la Constitución para evitar vernos tentados por los cantos de sirena (demagogia). Las Constituciones serían mecanismos de precompromiso o autorrestricción, elaboradas por el cuerpo político con el fin de protegerse a sí mismo contra su previsible tendencia a tomar decisiones imprudentes ${ }^{3}$. El propio Elster reconoce, sin embargo, que la autorrestricción que la Constitución supone no ha de ser entendida en sentido estricto. Las Constituciones se diseñan para hacer que sea difícil modificar sus disposiciones, pero no imposible ${ }^{4}$.

Esta idea se aprecia también en otros autores tanto europeos como norteamericanos, como Zagrebelsky, cuando apunta que si los jueces cedieran a la tentación de recurrir al consenso popular, no sólo traicionarían completamente su función, sino que se dejarían seducir por cantos de sirena que los conducirían al desastre ${ }^{5}$, o como Sunstein que señala que el precompromiso constitucional puede servir para salvar la debilidad de la voluntad por parte de la colectividad ${ }^{6}$.

Esta doctrina se completa, además, poco después por Stephen Holmes ${ }^{7}$, el cual parece salvar la principal objeción que se había hecho a la doctrina de Els-

2 ELSTER, J., «Introducción», en ELSTER, J. Y SLAGSTAD, R., Constitucionalismo y democracia, Fondo de Cultura Económica, México, 2001, págs. 40 y 41.

3 ELSTER, J., Ulises desatado ..., op. cit., págs. 111 y 112. Ciertamente, ELSTER no va tan lejos como el propio MONTESQUIEAU, quien diseñó su modelo de división de poderes como estructura de límites del poder y de garantía de los derechos y que afirmaba, en expresión de sus recelos a la omnipotencia del legislador, que los más de los legisladores han sido hombres de cortas luces y casi nunca han seguido más norte que sus antojos o preocupaciones. Vid. PRIETO SANCHÍS, L., Justicia constitucional y derechos fundamentales, Trotta, Madrid, 2009, pág. 55.

4 ELSTER, J., Ulises desatado ..., op. cit., págs. 117.

5 ZAGREBELSKY, G., Principios y votos. El Tribunal Constitucional y la política, Trotta, Madrid, 2008, pág. 99.

6 SUNSTEIN, C.R., "Constitutionalism and secession», University of Chicago Law Review, vol. 58, año 1991, pág. 641.

7 HOLMES, S., «El precompromiso y la paradoja de la democracia», en ELSTER, J. Y SLAGSTAD, R., op. cit., págs. 218 y ss. 
$\operatorname{ter}^{8}$ : la justificación de la autoconstricción fue ser admisible respecto de las generaciones presentes que lo deciden, pero ¿cómo justificarlo respecto a las generaciones futuras que no han participado, obviamente, en el pacto constitucional?? ${ }^{9}$ A este respecto, Holmes acude a un doble argumento. Por un lado, considera que la regla general que afirma que un individuo o una generación no puede obligar a otros encuentra una excepción básica, si junto a la herencia de la obligación se adquieren también derechos. Así, Holmes presenta al constitucionalismo como legado que, si bien compromete a la generación que lo recibe pero que no lo elaboró, también le aporta derechos y oportunidades. El marco constitucional sería una herencia, con sus bienes y deudas ${ }^{10}$. De este modo, la generación futura no sólo recibe la atadura, sino también el marco pacífico de convivencia que supone el respeto a un texto constitucional $^{11}$

El consentimiento tácito es, por lo tanto, fundamental para la propia sociedad civil. Lo contrario supone negar la propia realidad de la decisión política que debiera fundamentarse esencialmente en el logro de la justicia, no sólo hacia el presente inmediato, sino hacia el futuro. La exigencia de consentimiento expreso generacional rechaza la pretensión de búsqueda del bienestar futuro. Si cada generación ha de actuar de manera independiente, la generación actual no decidirá más allá de su mera extinción ¿Cuál será entonces el fundamento de todas esas políticas que aspiran a trascender a la generación que las crea sobre la base de fundamentarse en un principio de justicia que trasciende a los ciudadanos que lo impulsa y liga a la condición de ser humano? ¿Tendría entonces sentido diseñar políticas sociales o, más concretamente, medioambientales, si no podemos vincular con ellas a las generaciones futuras? ${ }^{12}$

Por otro lado, Holmes considera, además, que las ataduras son instrumento indispensable de la agencia humana que promueven libertades. Así, si podemos dar por sentados ciertos procedimientos e instituciones establecidas en el pasado, podremos alcanzar

8 WALDRON es el autor que más profunda y profusamente ha criticado la analogía de Ulises. Vid. WALDRON, J., Derecho y desacuerdos, op. cit. págs. 322 y ss. Un resumen de su crítica puede verse también en WALUCHOW, W.J., Una teoría del control judicial de constitucionalidad basada en el common law. Un árbol vivo, Marcial Pons, Madrid, 2009, págs. 232 a 234.

9 Esta objeción ya se planteó en los inicios del propio pensamiento político moderno. Así, HUME observó que existía una contradicción importante en la propia ficción del contrato social que daba fundamento a la teoría republicana, ya que ello suponía, a la postre, que los padres acabarían por anular el consentimiento no sólo de sus hijos, sino incluso de generaciones más remotas. En similares términos, LOCKE formuló la prohibición de que ningún padre puede atar a sus hijos. El pacto social únicamente constriñe a las generaciones presentes, idea esta que incluso se plasma normativamente en la Constitución jacobina de 1793: «una generación no puede someter a sus leyes a las generaciones futuras». Además, LOCKE emplea también en su discurso la idea del aumento del conocimiento de manera que el precompromiso es ilegítimo al amparo de la capacidad humana de aprendizaje y de autocorrección. El precompromiso sofoca la propia capacidad de aprender de las generaciones futuras.

10 HOLMES, S., «El precompromiso y la paradoja de la democracia», en ELSTER, J. Y SLAGSTAD, R., op. cit., pág. 234.

11 Ibidem, pág. 241.

12 Como apunta HOLMES, «si podemos establecer que generaciones subsiguientes tratarán con soberano desprecio nuestras elecciones hechas pensando en el futuro, ¿por qué habríamos de pensar más en el futuro que en el pasado?». Vid. HOLMES, S., «El precompromiso y la paradoja de la democracia», en ELSTER, J. Y SLAGSTAD, R., op. cit., pág. 243. 
nuestros actuales objetivos mejor de lo que podríamos lograrlo si estuviésemos siendo constantemente distraídos por la necesidad recurrente de establecer un marco básico para la vida política. Una Constitución heredada posibilita y estabiliza la democracia. La generación futura se libera de la compleja tarea que supone el constante debate generacional de renovación del texto constitucional. El precompromiso no esclaviza, sino que libera a las generaciones futuras ¿Debe convertirse cada generación en poder constituyente? Según el parecer de Holmes ello no es positivo, y no sólo porque el debate permanente reste posibilidades o dificulte alcanzar nuevos retos, sino porque, además, la frecuente convocatoria de convenciones constitucionales crearía periódicamente un vacío legal. La inevitable inestabilidad fruto del debate constituyente permanente reduciría la importancia del consentimiento popular, mientras que intensificaría el papel de la demagogia ${ }^{13}$.

En definitiva, nuestra democracia parece sustentarse, por obra del constitucionalismo, en una regla de la mayoría como procedimiento de decisión sujeta a restricciones sustantivas y tales restricciones traen fundamento en el marco jurídico-político que establece la Constitución. Cierto es que dicho marco no es inmutable, ya que, tanto a través de la reforma, como de la interpretación de lo que ha de ser considerado como un texto vivo (living constitution), pueden ir adaptándose las normas constitucionales y, por tanto, los límites que respecto del principio de mayoría consagran. Sin embargo, no es menos cierto que ambas opciones presentan sus problemas desde el punto de vista del principio democrático. La reforma exige un sobrecoste de mayoría que no se exige, habitualmente, para la aprobación del texto. Así pues, la mayoría quedaría constreñida a tener que alcanzar mucho más allá de la mayoría simple o, incluso, absoluta (más aún, cuando una de las características de las actuales Constituciones es su rigidez). Por lo que se refiere a la adaptación de la Constitución, quien la lleva a cabo no es sólo el Tribunal Constitucional, ya que a través de la labor legislativa puede producirse esta adaptación (en nuestro sistema, principalmente, a través de las leyes orgánicas). Sin embargo, la última palabra sobre la adaptación no la tiene la propia mayoría que la aprueba, ni siquiera el pueblo, sino un poder contramayoritario encarnado en el Tribunal Constitucional.

En todo caso, la gran mayoría de la doctrina ha venido considerando que el sobrecoste que supone esta autoconstricción es precisamente la que ha permitido que perviva el principio de democracia. Resulta realmente paradójico que el mejor instrumento que se haya ideado en los últimos tiempos para la pervivencia de la democracia sea precisamente algo que promueve limitar la propia democracia. En todo caso, así parece que se ha admitido de manera mayoritaria.

13 HOLMES, S., «El precompromiso y la paradoja de la democracia», en ELSTER, J. Y SLAGSTAD, R., op. cit., págs. 238 y 239. En este punto, HOLMES parece conectar con el clásico concepto de libertad de los modernos, postulada por CONSTANT, como primacía de los derechos individuales y que fundamenta el Estado liberal de Derecho en el que se diferencia entre público y privado, entre Estado y sociedad, y en el que los ciudadanos poseen el legítimo derecho a ocuparse de sus asuntos, delegando en los políticos la dirección de la comunidad, en contraposición a la denominada libertad de los antiguos. Los ciudadanos, siguiendo también a FERNÁNDEZ-MIRANDA en su defensa de la democracia representativa frente la democracia directa, se acabarían convirtiendo en permanentes activistas constitucionales de todas las causas, lo que supondría un empobrecimiento económico de la sociedad por la falta de tiempo para actividades privadas y para la prosperidad de la sociedad. Vid. FERNÁNDEZ-MIRANDA CAMPOAMOR, C. y FERNÁNDEZ-MIRANDA CAMPOAMOR, A., Sistema electoral, partidos políticos y Parlamento, Colex, Madrid, 2003, págs. 26 y 27. 
Como muy bien apuntaba Ahumada Ruiz desde una perspectiva histórica, lo que hace grande a Marbury v. Madison no es el fallo ni la argumentación ni el caso objeto de resolución, sino el debate que sucedió a la decisión y que aún sigue en plena vigencia. Marbury es un caso intemporal y universal porque propone la solución del control judicial de inconstitucionalidad donde los jueces han de tener en una democracia la última palabra frente a la mayoría, lo que no tiene una respuesta obvia y con la que de alguna forma todos los cursos de Derecho constitucional pelean de principio a fin ${ }^{14}$. Y ello puede que en el fondo no sea tan paradójico porque como bien expresa Linares, el constitucionalismo encierra un doble compromiso difícil de cohonestar: un compromiso con la idea de derechos (dimensión sustantiva) y un compromiso con la idea de democracia (dimensión procedimental) ${ }^{15}$.

En todo caso, no hay que olvidar que el constitucionalismo ha triunfado allí donde el poder contra-mayoritario se ha impuesto al Parlamento, es decir, ahí donde la constitución ha atado la democracia. El poder que se otorga a los Jueces en el control de la Constitución no es, a la postre, otra cosa que control del propio Parlamento ${ }^{16}$.

\section{II. ¿VUELTA A LA PRIMACÍA DEL PARLAMENTO O DIÁLOGO ENTRE LOS PODERES MAYORITARIO Y CONTRAMAYORITARIO?}

El paradigma en el que se ha venido fundamentando nuestro actual constitucionalismo podría estar cambiando. Pocos han puesto en duda, desde los conocimientos del Derecho constitucional, la virtualidad del sistema y cómo el mismo sirve para la pervivencia de la propia democracia, sobre todo, tras la experiencia vivida en la primera mitad del siglo XX. Frente a lo que se ha mostrado como un principio poco discutible, salvo en algunos espacios dejados al debate de la Filosofía política, ya se alzan no sólo voces, sino propuestas y nuevas figuras que parecen informar que el viejo debate acerca de quién ha de tener la última palabra, el poder contramayoritario o los representantes que encarnan la voluntad del pueblo, pudiera resurgir nuevamente.

Preguntas tales como, ¿cómo puede ser que, en una democracia, los jueces tengan la posibilidad de anular una ley aprobada por los representantes de la mayoría del pueblo? o ¿cómo puede ser que un minúsculo grupo de jueces, que no son elegidos directamente por la ciudadanía y que no están sujetos a periódicas evaluaciones populares puedan hacer prevalecer su voluntad sobre la del pueblo? ${ }^{17}$, empiezan a tener ya una contestación

14 AHUMADA RUIZ, M., «Marbury versus Madison doscientos años (y más) después», Fundamentos, núm. 4, Oviedo, 2006, págs. 125, 126 y 149.

15 LINARES, S., La (i)legitimidad democrática del control judicial de las leyes, Marcial Pons, Madrid, 2008, pág. 45.

16 El poder contra-mayoritario actúa como un incentivo para que el legislador proteja los derechos y libertades. Aquél, en palabras del Juez CARDOZO, permanece en la antesala, pero siempre alerta, y ello influye en la labor del legislador que buscará la decisión que en mayor medida respete la voluntad constitucional. Vid. CARDOZO, B., The nature of judicial process, Yale University Press, New Haven, 1921. Referencia tomada de WALUCHOW, W.J., Una teoría del control judicial de constitucionalidad ..., op. cit., pág. 345.

17 GARGARELLA, R., La justicia frente al gobierno. Sobre el carácter contramayoritario del poder judicial, Ariel, Barcelona, 1996, págs. 11 a 13. Vid., en similares términos, GRASSO, P. G., El problema del constitucionalismo después del Estado moderno, Marcial Pons, Madrid, 2005, pág. 50. 
normativa concreta que pretende recuperar la primacía del Parlamento frente al poder contra-mayoritario.

Dentro de esta corriente doctrinal, Nino propone, para salvar los riesgos del principio de mayoría, un modelo de democracia que se fundamente en el diálogo, no en la mera expresión del principio de la mayoría. Esta sería una vía apta para llegar a soluciones que tienen una mayor probabilidad de ser moralmente correctas que las soluciones que se dictan a través de otros procedimientos, y ello, porque la discusión generalizada, amplia, abierta y la decisión mayoritaria promueven procedimientos que tienden a la imparcialidad y al conocimiento de los hechos relevantes, permitiendo que todos o una buena parte de la población hagan conocer a través del proceso democrático cuáles son sus intereses $^{18}$.

Dentro de este modelo, la jurisdicción constitucional tendría como función la de controlar que la mayoría no restrinja las condiciones y los presupuestos que hacen del procedimiento democrático un mecanismo apto para encontrar soluciones correctas. La misma mayoría que podría estar viciada por fallas en las condiciones de la discusión amplia, abierta y de la decisión mayoritaria es obvio que no puede decidir sobre si esas condiciones se dan, porque esa decisión estaría afectada por los mismos defectos que se estaría discutiendo, si se satisfacen o no. Es por ello que es necesario contar con órganos independientes que controlen si esos presupuestos y esas condiciones del procedimiento de discusión, de debate y de decisión democrática se han satisfecho o no; órganos cuya propia legitimidad no dependa de avatares, de mayorías que pueden estar afectadas por las fallas ${ }^{19}$.

Sin embargo, esto parece que promueve una jurisdicción constitucional fundamentada en el procedimiento, con un olvido absoluto de los valores que la propia Constitución consagra, es decir, un olvido de la parte dogmática en mero beneficio de la parte orgánica de la Constitución, cuando aquélla no sólo es una parte relevante del texto constitucional, sino más aún, es el presupuesto de la misma. Además, si hemos admitido que la Constitución es una norma integrada fundamentalmente por valores, situar el debate de la jurisdicción constitucional en el ámbito de los procedimientos (reglas) supone excluir el control de los valores.

Por otro lado, el problema radica también en que la interpretación de lo que es y no es control procedimental admite tanto una posición restrictiva como muy amplia, de manera que se incurriría en lo que precisamente pretende Ely evitar, el control material ${ }^{20}$. Variando ligeramente las coordenadas ideológicas, el propósito restrictivo del control de constitucionalidad se esfumaría y la justicia constitucional recobraría toda su competencia sobre el conjunto de la normativa constitucional ${ }^{21}$.

18 NINO, C.S., «La filosofía del control judicial de constitucionalidad», Revista del Centro de Estudios Constitucionales, núm. 4, septiembre-diciembre, 1989, pág. 87.

19 Ibidem, pág. 87. De este modo, NINO se sitúa en una posición muy próxima a ELY que igualmente proponía limitar los poderes de la jurisdicción constitucional al control de la satisfacción por los órganos democráticos del procedimiento establecido constitucionalmente para la toma de decisiones. Vid. ELY, J.H., Democracy and Distrust. A Theory of Judicial Review, Harvard University Press, Cambridge, 1980. Existe una edición en castellano, en ELY, J.H., Democracia y desconfianza, Siglo del Hombre Editores, Universidad de los Andes, Santafé de Bogotá, 1997.

20 NINO, C.S., «La filosofía del control judicial de constitucionalidad», cit., pág. 87.

21 PRIETO SANCHÍs, L., Justicia constitucional..., op. cit., pág. 161. 
Por otro lado, de esta postura se deduce un temor al propio principio mayoritario que es capaz, no sólo, de modificar las propias reglas de juego para impedir el debate con la minoría, sino también, y por qué no, de suprimir los derechos fundamentales consagrados en el texto constitucional. Es decir, dichos autores acaban por reconocer las imperfecciones y riesgos del modelo democrático. Sin embargo, limitan sus temores a la alteración por la mayoría de las reglas de juego procedimentales, cuando el riesgo de alteración de los valores y derechos fundamentales también está siempre presente.

En todo caso, el propio Nino admite que su posición puede tener una interpretación muy restringida o una interpretación bastante amplia. Puede tener una interpretación restringida si pensamos que el papel de los jueces debe limitarse a verificar si se dieron las condiciones procedimentales del debate y de la decisión democrática. Pero él no considera que ello deba ser así, pues la validez de una decisión mayoritaria depende de muchas cosas. Y, de este modo, decisiones jurisprudenciales tales como la emitida por el Tribunal Supremo de los Estados Unidos de América en Brown vs. Board of Education, que trata de superar la discriminación racial en materia educativa, están absolutamente justificadas bajo esta visión de la democracia porque a través de estos fallos se intenta, en última instancia, poner a todo el mundo en igualdad de condiciones para que puedan participar del debate y de la decisión democrática y maximizar de esa manera el valor epistemológico de la democracia ${ }^{22}$.

Gran parte de las nuevas propuestas que pretenden superar a través de diferentes instrumentos político-constitucionales los problemas que presenta el poder contra-mayoritario no se asientan ya exclusivamente en la mera virtud del principio de la mayoría, sino en la promoción de la deliberación, de la democracia deliberativa, dentro del debate constitucional. Así, la jurisdicción constitucional se presentaría como instrumento de un sistema político en el cual la democracia deliberativa sería el método adecuado para tomar decisiones, de modo tal que los Tribunales, al resolver los problemas de constitucionalidad sometidos a su jurisdicción, se verían implicados en un proceso de deliberación en el que, con la información suficiente, serían capaces de buscar de forma consciente el bienestar colectivo, serían capaces de tomar la solución más justa, serían capaces de acercarse a la verdad moral ${ }^{23}$. Así, donde una decisión judicial sobre la constitucionalidad queda abierta a ser contradicha, modificada o evitada, se permite crear un diálogo entre la Corte y poder legislativo ${ }^{24}$.

Otro planteamiento propone también formas débiles de control de la constitucionalidad que permitan, sin suprimir la judicial review, que la última palabra recaiga en el Parlamento, y ello, sobre la base de que el control que ejercen los Tribunales sobre los derechos sociales supone, a la postre, una invasión de competencias que corresponden al poder legislativo y, en su caso, al ejecutivo ${ }^{25}$.

22 NINO, C.S., «La filosofía del control judicial de constitucionalidad», cit., págs. 87 y 88.

23 GÓMEZ FERNÁNDEZ, I., «Una aproximación al Tribunal Constitucional español desde la teoría de la democracia deliberativa», Revista General de Derecho Constitucional, Iustel, núm. 2, octubre 2006.

24 HOGG, P. W. y BUSHELL, A.A., «The Charter dialogue between Courts and Legislatures: (or perhaps the Charter of Rights isn't such a bad thing after all», Osgoode Hall Law Journal, vol. 35, núm. 1, 1997, pág. 79.

25 TUSHNET, M., Weak Courts, strong rights: judicial review and social welfare rights in Comparative Constitutional Law, Princeton University Press, Princeton, 2008, pág. XI. Vid., también, TUSHNET, M., «The rise of weak-form judicial review», en GINSBURG, T. y DIXON, R. (Edits.), Comparative constitutional Law, Edward Elgar, Cheltenham, 2011, págs. 321 a 333. 
Entre las nuevas fórmulas que permiten que la última palabra no esté en manos del poder contra-mayoritario encontramos soluciones que van desde la mera ausencia de efectos anuladores de la declaración de inconstitucionalidad de la ley hasta la devolución del texto al Parlamento autor para que, a través de una fórmula próxima al override del veto presidencial, pueda salvar con una nueva votación la declaración de inconstitucionalidad y sus efectos ${ }^{26}$.

En definitiva, se trata de propuestas que van desde la pretensión de reinstaurar la primacía del Parlamento, como institución que goza de la máxima legitimidad que le viene conferida por el carácter electivo de sus miembros, hasta fórmulas mixtas de constitucionalismo débil ${ }^{27}$. En estas últimas se pretenden obtener fórmulas que conjuguen el procedimiento democrático con el control jurisdiccional de la constitucionalidad. Es decir, lo que siguiendo la metáfora de Elster sería, seguir atados, pero con las cuerdas algo más sueltas.

Nosotros en nuestro trabajo nos referiremos, para ilustrar este cambio, a una propuesta muy concreta que surge en uno de los modelos constitucionales de referencia, sobre todo, en Estados descentralizados como es el modelo canadiense. Así, vamos a estudiar a continuación las cláusulas denominadas notwithstanding y override que suponen, lisa y llanamente, devolver la última palabra al Parlamento en detrimento de las clásicas atribuciones del poder contramayoritario (en dicho Estado, fundamentalmente, el Tribunal Supremo).

\section{LAS CLÁUSULAS NOTWITHSTANDING Y OVERRIDE DEL CONSTITUCIONALISMO CANADIENSE}

Entre los modelos que suponen que la última palabra sobre la interpretación de la Constitución no esté ya en manos del Tribunal Constitucional o en los Tribunales ordinarios de Justicia ${ }^{28}$, sino en el Parlamento, debemos destacar Canadá que, a través de la Carta de Derechos y Libertades, la cual forma parte de la Constitución de $1982^{29}$, in-

26 Incluso, el país en el que encuentra su origen la judicial review existe un movimiento doctrinal que pretende instaurar una especie de provisional review, de manera que las decisiones acabaran por someterse a un último control por parte del Congreso. Vid. LAFUENTE BALLE, J.M., La judicialización de la interpretación constitucional, Colex, Madrid, 2000, pág. 27. TUSHNET encuentra en las ideas de Jefferson el precedente de estas nueva forma de control constitucional débil (weak-form review). Vid. TUSHNET, M., Weak Courts, strong rights: ..., op. cit., pág. 16. Vid., también, GOLDSWORTHY, J., «Homogenizing constitutions», Oxford Journal of Legal Studies, vol. 23, núm. 3, año 2003, pág. 484.

27 Sobre esta nueva forma de constitucionalismo débil, véase BAYÓN, J.C., «Derechos, democracia y Constitución», en CARBONELL, M. (Edit.), Neoconstitucionalismo(s), Trotta, Madrid, 2003, pág. 235.

28 Otros Estados en los que se han recogido fórmulas que permiten al Parlamento salvar las objeciones presentadas por parte de la Justicia Constitucional son Países Bajos y Suecia. En el primero, los jueces no pueden anular una Ley, pero sí formular su parecer interpretativo sobre la misma, frente a lo que el Parlamento puede emitir una Ley interpretativa que rechace la interpretación judicial. Por su lado, en Suecia, para enmendar un catálogo de derechos que goza de protección constitucional, se puede aprobar una ley, pero en dos votaciones distintas con nueve meses de distancia. Por último, en el Reino Unido, tras la aprobación de la $H u$ man Rights Act de 1998, por la que se incorpora al ordenamiento jurídico británico la Convención Europea de Derechos Humanos y la doctrina emanada del Tribunal Europeo de Derechos Humanos, se establece que cuando un Juez considere que una norma del Parlamento contradice su contenido (declaración de incompatibilidad), 
corpora las denominadas cláusulas notwithstanding y override $e^{30}$. Así, en el artículo 33 de la Carta de Derechos y Libertades se establece que si el Parlamento nacional o una Asamblea de una provincia aprueba una Ley, incorporando una cláusula notwithstanding, la convierte en inmune frente a la justicia constitucional. Igualmente, puede acudirse a dicha fórmula para aprobar una Ley frente a una decisión judicial posterior a su aprobación que la declare inconstitucional y así hacerla inmune ${ }^{31}$.

En similares términos, el Parlamento nacional o la Asamblea de una provincia pueden acordar que una norma que ha sido declarada contraria a la Carta de Derechos y Libertades por la Justicia Constitucional siga en vigor cinco años más. Tal prórroga de la norma inconstitucional es susceptible de ser renovada por más periodos de cinco años. El plazo de cinco años se corresponde con el plazo de duración de la legislatura, de manera que los ciudadanos puedan decidir a través de la renovación de las Cámaras si se muestran o no conformes con la decisión de suspender la decisión constitucional de inconstitucionalidad.

Así pues, con la incorporación de las citadas cláusulas, la norma se hace inmune al control de constitucionalidad, tanto a priori como a posteriori. Sin embargo, dichas cláusulas sólo pueden emplearse respecto de los derechos proclamados en los artículos 2 y 7 a 15 de la $\mathrm{Carta}^{32}$. De este modo, derechos tales como los derechos políticos de sufragio

la norma sigue aplicándose hasta que el Parlamento la modifique o derogue. Sin embargo, también se admite que el Parlamento no haga nada al respecto, por lo que la norma incompatible no se verá afectada por la decisión judicial. Tal declaración no tiene, en consecuencia, un verdadero valor jurídico de manera que pudiera producir la nulidad o expulsión del ordenamiento de la norma, pero sí promueve el diálogo interorgánico entre Parlamento y el Tribunal en orden a lograr una modificación normativa que salve dicha incompatibilidad.

29 Con anterioridad a la Carta, los derechos y libertades estaban protegidos no por la Constitución, sino por una combinación de legislación ordinaria, tradición, práctica política y doctrinas jurídicas. Vid. BASTARECHE, M., «La Carta canadiense de los Derechos y de las Libertades y la sociedad canadiense», conferencia, La Carta canadiense de derechos y libertades. Los primeros 25 años, Fundación Manuel Giménez Abad, Zaragoza, 7 de junio de 2007, pág. 2. Puede accederse a dicho trabajo a través de la página web de la Fundación, en www.fundacionmgimenezabad.es.

30 La doctrina, incluida la canadiense, no distingue claramente entre ambas cláusulas, de manera que pudiera afirmarse que, al amparo del artículo 33 de la Carta de Derechos al que nos vamos a referir de inmediato, se hayan incorporado dos figuras con naturaleza y singularidad propia. Parece, por el contrario, que ambos términos, notwithstanding y override, se emplean indistintamente, respondiendo a dos maneras distintas de denominar a la misma figura. Sin embargo, en ocasiones, podría deducirse lo contrario, de modo que el término notwithstanding quedara reservado para aquellos supuestos en el Parlamento acude a la cláusula a priori, de manera que la Ley aprobada quede blindada frente a futuras decisiones de los Tribunales, mientras que el término override se referiría ya a aquellos casos en los que se acude a la cláusula a posteriori, es decir, para salvar una decisión de inconstitucionalidad del Tribunal.

31 Los términos literales en los que se expresa la cláusula son los siguientes:

"(1) Parliament or the legislature of a province may expressly declare in an Act of the Parliament or of the legislature, as the case may be, that the Act or a provision thereof shall operate notwithstanding a provision included in section 2 or sections 7 to 15 of this Charter.

(2) An Act or a provision of an Act in respect of which a declaration made under this section is in effect shall have such operation as it would have but for the provision of this Charter referred to in the declaration.

(3) A declaration made under subsection (1) shall cease to bave effect five years after it comes into force or on such earlier dates as may be specified in the declaration.

(4) Parliament or the legislature of a province may re-enact a declaration made under subsection (1).

(5) Subsection (3) applies in respect of a re-enactment made under subsection (4)».

32 Entre tales derechos y libertades se encuentran la libertad ideológica, religiosa, de expresión y de reunión y asociación (art. 2), el derecho a la vida e integridad y a la libertad personal y seguridad (arts. 7 a 14) y el derecho a ser discriminado (art. 15). 
activo y pasivo o similares, los derechos de circulación y libre elección de residencia o los derechos lingüísticos no pueden ser verse afectados por las precitadas cláusulas ${ }^{33}$.

Por último, el recurso a la cláusula ha de recogerse en una norma con rango de ley y, además, ha de establecerse expresamente, no admitiéndose la forma tácita ${ }^{34}$.

\section{ORIGEN Y FUNDAMENTO DE LAS CLÁUSULAS}

Las fórmulas que consagra el artículo 33 de la Carta no constituyen algo inédito, sino que encuentran su precedente en algunas leyes provinciales que ya consagraran cláusulas similares. Así, the Saskatchewan Human Rights Code, the Alberta Bill of Rights y the Quebec Charter of Human Rights, establecen que sus disposiciones prevalecen sobre las demás leyes, salvo que por el Parlamento invoque la cláusula override ${ }^{35}$. Igualmente, al aprobarse en Canadá el precedente de la Carta, la Ley de Derechos de 1960, se incluye una fórmula notwithstanding en su artículo 2 que disponía que los derechos y libertades consagrados en la misma habían de ser respetados por las leyes que fueran aprobadas por el Parlamento, salvo que el propio Parlamento estableciera expresamente que la norma habrá de operar a pesar de la Ley de Derechos. El motivo de esta previsión, denominada entonces nonobstante clause, no fue otro que el temor a que la aprobación de la Ley de Derechos pudiera actuar en detrimento del principio de soberanía del Parlamento ${ }^{36}$. Sin embargo, la prudente posición que mantuvo el Tribunal Supremo una vez aprobada dicha Ley, promovió un clima política y jurídicamente favorable a que los derechos y libertades quedaran consagrados ya en un documento constitucional de mayor rango normativo, como era una Carta de Derechos ${ }^{37}$.

De este modo, las cláusulas se acabarán incorporando a la Carta de Derechos al amparo del fenómeno de la patriation ${ }^{38}$, en virtud del cual, el modelo constitucional canadiense pasará de estar regulado por una Ley británica cuya modificación exigía la aprobación del Parlamento británico, a estar fundado exclusivamente en una norma constitucional aprobada por Canadá, Canada Act, 1982. Se trata del proceso político por

33 Algún autor ha criticado este aspecto de la regulación de las cláusulas, ya que de tal distinción podría deducirse que existe una jerarquía entre derechos. Vid. JOHANSEN, D. y ROSEN, P., «The notwithstanding clause of the Charter», Parliamentary Information and Research Service, Library of Parliament, 2008, pág. 16. Puede accederse a este trabajo a través de la página web del Parlamento canadiense, en www.parl.gc.ca.

34 JOHANSEN, D. y ROSEN, P., «The notwithstanding clause of the Charter», cit., pág. 2. Puede accederse a este trabajo a través de la página web del Parlamento canadiense, en www.parl.gc.ca.

35 LEESON recuerda también que la fórmula notwithstanding era ya conocida en el Derecho canadiense y se empleaba mucho tiempo atrás como técnica legislativa, cuando dentro de un texto normativo se apreciaba una contradicción, de manera que a través de la fórmula se determinaba qué interpretación había de prevalecer. También, tal posibilidad de que se aprobaran determinadas regulaciones en Canadá sin que ello hubiera de afectar necesariamente a todo el territorio es algo que ha estado permanentemente presente en la evolución de su Derecho constitucional. Vid. LEESON, H., «Section 33, the Notwithstanding Clause: a paper tiger?», Choices. Institute for Research on Public Policy, vol. 6, núm. 4, junio 2000, pág. 6.

36 LEESON, H., «Section 33, the Notwithstanding Clause: a paper tiger?», Choices. Institute for Research on Public Policy, vol. 6, núm. 4, junio 2000, pág. 7.

37 Ibidem, pág. 7.

38 El término fue empleado por primera vez por el Primer Ministro de Canadá, Pearson, en 1966, en respuesta a una pregunta en el Parlamento. 
el que Canadá adquiere plena soberanía política frente al Reino Unido, debiendo ya en el futuro resolver por sí misma sus cuestiones constitucionales sin tener que acudir al Parlamento británico.

En las reuniones (Conferencias) celebradas al amparo de la patriation, se discutió la naturaleza y contenido de dicho nuevo orden constitucional, ya que el temor de las provincias era que el proceso se aprovechara para impulsar una centralización del modelo territorial, asumiendo el Gobierno central un mayor número de competencias y poderes ${ }^{39}$. El Primer Ministro Trudeau pretendía, a través de la creación del nuevo orden constitucional, aprobar una regulación de derechos y libertades, siguiendo la tradición existente en Europa. Sin embargo, para los líderes políticos de las provincias, tal pretensión levantaba suspicacias, y ello, porque ni respondía a la tradición canadiense, basada, por influencia británica, en el principio de la supremacía del Parlamento, y, además, porque no resultaba claro cuál había ser el alcance de tal declaración ${ }^{40}$. Además, la situación de enfrentamiento político entre el Gobierno central y algunas provincias se había complicado tras haber declarado el Tribunal Supremo, en contestación a una consulta acerca de si el proceso de patriation había de contar o no con el parecer favorable de las provincias, que, si bien formalmente el Gobierno nacional podía promover tal proceso por sí mismo, hacerlo sin consentimiento de un importante número de provincias violaría una convención constitucional no escrita ${ }^{41}$.

Siento tal el contexto, el Primer Ministro de la provincia de Saskatchewan propuso incluir en la regulación de derechos y libertades una fórmula que permitiera a los Parlamentos salvar (override) una decisión de la Corte hecha al amparo de la regulación. La propuesta fue admitida por el Primer Ministro Trudeau, pero exigiendo que la cláusula tuviera una eficacia limitada a los cinco años. De este modo, surge la figura en los términos que aparece regulada en el artículo 33 de la Carta. Pese a tal acuerdo, debe recordarse que la provincia de Quebec siguió oponiéndose a la Carta, ya que la cláusula override que incorporaba no surtía efectos respecto de los derechos lingüísticos ${ }^{42}$.

Como ha apuntado Leeson acerca de la realidad de este proceso de creación de las cláusulas, y como ha ocurrido muy habitualmente en la historia y evolución del propio Derecho constitucional, «the particular version that emerged in November 1981 and was ultimately enacted in 1982 had more to do with the raw politics of bargaining and chance phone calls late at night than with reasoned debate about what might constitute a rational compromise between democracy and constitutional law» ${ }^{43}$.

39 TUSHNET, M., «Policy distortion and democratic debilitation: comparative illumination of the countermajoritarian difficulty», Michigan Law Review, vol. 94, núm. 2, noviembre 1995, pág. 277.

40 TUSHNET, M., «Policy distortion and democratic debilitation: ...», cit., pág. 278.

41 In Re Amendment in the Constitution of Canada, 1981. Un debate jurídico-político similar se produjo en el Reino Unido con la aprobación de la Human Rights Act, 1998, en virtud de la cual, se incorpora al sistema constitucional británico la Convención Europea de Derechos Humanos y que suscitó la duda acerca de cuál sería, a partir de su aprobación, los efectos de una decisión judicial que considerara que una norma del Parlamento británico era contraría al contenido de la Human Rights Act.

42 Recuérdese que los derechos lingüísticos aparecen regulados en los artículos 16 a 23 respecto de los que no cabe recurrir a las cláusulas.

43 LEESON, H., «Section 33, the Notwithstanding Clause: a paper tiger?», op. cit., págs. 3 y 4. 
En cuanto a su razón de ser de las cláusulas, podemos destacar tres motivos principales. En primer lugar, las cláusulas permiten combinar las bondades de un sistema de judicial review con las del sistema de supremacía del Parlamento ${ }^{44}$. Como ha puesto de manifiesto la doctrina en Canadá, se trata combinar tanto la protección de los derechos y libertades consagrados en la Carta como preservar cierto grado de supremacía del Parlamento $^{45}$. Pretende satisfacerse tanto a aquellos que se muestran favorables a promover la judicial review como a aquellos que postulan la supremacía del Parlamento ${ }^{46}$. Un compromiso entre los firmes defensores del modelo norteamericano de control de constitucionalidad y los firmes defensores del modelo británico (a new constitutional equilibrium $)^{47}$. Ni los Tribunales tendrán la última palabra, ni el Parlamento puede recurrir a la cláusula respecto de todos los derechos ni por un periodo de tiempo incierto ${ }^{48}$. Se trata, pues, de una fórmula de equilibrio entre los poderes de los órganos judiciales y de los legisladores que proporciona la flexibilidad que se requiere para garantizar que éstos y no aquéllos tengan la última palabra en materia de las políticas públicas ${ }^{49}$. Permiten, como se ha apuntado por algún autor, distinguir entre la facultad de controlar la constitucionalidad de las leyes y la posibilidad de que los jueces puedan sustituir las decisiones políticas cuando se encuentren involucrados derechos y libertades ${ }^{50}$.

44 En palabras de GOLDSWORTHY, «uniquely Canadian compromise of two rival constitutional models - the American model of strong judicial review, and the British model of parliamentary sovereignty». Vid. GOLDSWORTHY, J., «Judicial review, legislative override, and democracy», Wake Forest Law Review, vol. 38, año 2003, pág. 453.

45 BASTARECHE, M., «Section 33 and the relationship between Legislatures and Courts», en VVAA, Courts and Legislatures: the terms of the discourse, Constitutional Forum Constitutionnel, vol. 14, núm. 3, 2005, pág. 2.

46 BASTARECHE ilustra su explicación del cambio que la Carta ha supuesto para el sistema jurídico canadiense y para el equilibrio entre el poder judicial y legislativo con un caso concreto acerca del aborto (caso Dr. Morgentaler). Así, un médico que había sido condenado por la práctica de abortos ilegales antes de la aprobación de la Carta, no encontrando ningún fundamento jurídico el Tribunal Supremo para poder considerar que la norma penal que criminalizaba dichos abortos fuera inconstitucional, es absuelto cuando años después es nuevamente juzgado por otros casos similares, estando ya en vigor la Carta. El Tribunal consideró entonces que la regulación del aborto era contraria al art. 7 de la Carta, declarando su nulidad y la consiguiente absolución del galeno. Vid. BASTARECHE, M., «La Carta canadiense de los Derechos y de las Libertades y la sociedad canadiense», cit., págs. 4 a 6 . Puede accederse a dicho trabajo a través de la página web de la Fundación, en www.fundacionmgimenezabad.es.

47 HIEBERT, J.L., «Compromise and the Notwithstanding Clause: why the dominant narrative distorts our understanding», 2007 Conference, Canadian Political Science Association, pág. 5. Puede accederse a dicha ponencia a través de la página web de la Canadian Political Science Association, en www.cpsa-acsp. ca. Esta ponencia ha sido también publicada en KELLY, J.B. y MANFREDI, C.P. (Eds), Contested constitutionalism. Reflections on the Canadian Charter of Rights and Freedoms, UBC Press, Vancouver, 2009, págs. 107 y ss.

48 FRASER, C.A., «Constitutional dialogues between Courts and Legislatures: Can we talk?», en VVAA, Courts and Legislatures: the terms of the discourse, Constitutional Forum Constitutionnel, vol. 14, núm. 3, 2005 , págs. 9 y 10 .

49 Palabras pronunciadas por el Ministro de Justicia de Canadá en la Conferencia de Primeros Ministros celebrada en noviembre de 1981, en la que se discutió acerca de la oportunidad de incluir las cláusulas en la futura Carta. Vid. JOHANSEN, D. y ROSEN, P., «The notwithstanding clause of the Charter», cit., pág. 8. Puede accederse a este trabajo a través de la página web del Parlamento canadiense, en www.parl.gc.ca.

50 HIEBERT, J.L., «Constitucional experimentation: rethinking how a bill of rights functions», en GINSBURG, T. y DIXON, R. (Edits.), Comparative constitutional Law, Edward Elgar, Cheltenham, 2011, pág. 298. 
A este respecto, debe recordarse, como acabamos de apuntar antes, que el origen de las cláusulas responde a un pacto entre el gobierno central y las provincias de manera que se satisface tanto la pretensión de aquel de promover un sistema de garantía y protección de los derechos y libertades fundado en una norma de rango constitucional, como la pretensión de éstas de respetar la tradición jurídica sustentada en la supremacía del Parlamento.

En segundo lugar, las cláusulas promueven una forma de democracia constitucional fundada en el diálogo entre los poderes (the dialogue metaphor). Se trataría de "an integral component of a more comprehensive and sophisticated democratic discourse» ${ }^{51}$. El control de constitucionalidad que ejerce el Tribunal Supremo canadiense se vería completado por la posibilidad que se atribuye al legislador, nacional o regional, de contradecir, modificar o evitar tal decisión, creándose un diálogo entre ambos poderes ${ }^{52}$.

Para Tushnet tal diálogo permite, además, incorporar al propio electorado, en la medida que la eficacia del recurso a la cláusula tiene un límite temporal de cinco años. De este modo, si bien tal participación del electorado no se producirá de inmediato, sí al menos antes de decidir acerca de la prórroga cinco años más de la cláusula, en la medida que en tal momento ya se habrán celebrado unas elecciones en las que el recurso a la cláusula por la, entonces, mayoría parlamentaria podrá haber sido uno de los temas a debatir en la campaña ${ }^{53}$. Las cláusulas pueden promover la democratización del sistema, al permitir a los ciudadanos y a sus representantes la discusión acerca de problemas constitucionales en sede parlamentaria ${ }^{54}$.

Sin embargo, frente a ello se ha apuntado que la metáfora del diálogo entre poderes que parecen promover las cláusulas no es tal, en lo que se refiere a las cláusulas notwithstanding, ya que el Parlamento no recurre a estás tras una decisión de inconstitucionalidad por parte del Tribunal, sino con carácter preventivo, es decir, antes de que se produzca dicha decisión y precisamente para evitarla, blindando la ley respecto de dicha posibilidad. Ello, en modo alguno promueve el diálogo, ya que el Parlamento no parece ya muy dispuesto a entablar una conversación con la Corte, sino, contrariamente, a evitarla ${ }^{55}$.

51 Palabras pronunciadas por el Justice Iacobucci en Vriend v. Alberta, 1998. Vid. MANFREDI, C.P. y KELLY, J.B., «Six degrees of dialogue: a response to Hogg and Bushell», Osgoode Hall Lw Journal, vol. 37, núm. 3, 1999, pág. 514.

52 HOGG, P. W. y BUSHELL, A.A., «The Charter dialogue between Courts and Legislatures: ...», cit., pág. 79. MANFREDI y KELLY critican la metáfora del diálogo que desarrollan HOGG y BUSHELL al considerar que el análisis de resoluciones en el que fundamentan la misma incurre en varias imperfecciones, sobre todo, al tomar sólo en cuenta los casos en los que la Corte se ha limitado a anular una norma por su contradicción con la Carta, lo que supone una minoría de los casos en comparación con aquellos otros en los que la Corte ha optado por una sentencia de naturaleza interpretativa, salvando de este modo la inconstitucionalidad, siendo ésta, además, la opción más habitual. El diálogo se produce, en definitiva, sólo en un tercio de los casos en los que se ha acudido a las cláusulas de manera que, si bien, el recurso a las cláusulas puede producir diálogo entre la Corte y el Parlamento, ello sólo es así en una pequeña parte de los casos. Vid. MANFREDI, C.P. y KELLY, J.B., «Six degrees of dialogue: ...», cit., págs. 515 a 521. En nuestra país, puede destacarse que Linares mantiene una opinion muy similar. Vid. LINARES, S., La (i)legitimidad democrática del control judicial de las leyes, Marcial Pons, Madrid, 2008, pág. 22.

53 TUSHNET, M., «Policy distortion and democratic debilitation: ...», cit., p pág. 280.

54 Ibidem, pág. 284.

55 MANFREDI, C.P. y KELLY, J.B., «Six degrees of dialogue: ...», cit., pág. 522. Vid., en similares términos, CAMERON, J., «The Charter's legislative override: feat or figment of the constitutional imagination» en HUSCROFT, G. y BRODIE, I., Constitutionalism in the Charter era, Lexis Nexis, Ontario, 2004, pág. 151. 
Por último, otras de las razones a las que responden las cláusulas y que, como veremos, constituye ya la única que prácticamente les da fundamento, atendiendo a la evolución que han tenido, es del de la forma de organización territorial canadiense. En efecto, las cláusulas no sólo responden al temor de que el poder judicial pueda pretender, al amparo de la Carta, asumir poderes políticos respecto del Parlamento nacional, sino también que la uniformidad en la regulación de los derechos y libertades que supone la Carta pueda afectar a las competencias de las provincias que integran la Federación ${ }^{56}$. Las cláusulas presumen un reconocimiento del hecho diferencial en la esfera de determinados derechos y libertades.

\section{SU VIRTUALIDAD Y FUTURO EN EL CONSTITUCIONALISMO CANADIENSE. ANÁLISIS DE CASOS}

\section{UN DESUSO CASI UNÁNIME}

El recurso a las cláusulas ha sido meramente excepcional en Canadá. El Parlamento nacional nunca ha hecho uso de las mismas. Solamente ha existido alguna propuesta parlamentaria concreta de recurrir a ellas con ocasión de alguna Ley, como fue el proyecto de Ley sobre matrimonio entre personas del mismo sexo. Durante el debate de dicha Ley, aprobada en 2005, algunos miembros del Parlamento propusieron el uso de la cláusula notwithstanding con el fin de que el concepto jurídico de matrimonio quedara circunscrito a la unión entre hombre y mujer. Sin embargo, tal propuesta no encontró apoyo en el Parlamento, de manera que la definitiva Ley sobre matrimonio, Civil Marriage Act, aprobada ya en la siguiente legislatura vendría a recoger en su Preámbulo una exclusión expresa del recurso a la cláusula en los siguientes términos: «the Parliament of Canada's commitment to uphold the right to equality without discrimination precludes the use of section 33 of the Canadian Charter of Rights and Freedoms to deny the right of couples of the same sex to equal access to marriage for civil purposes».

Más recientemente, en 2009, se propuso incluir una cláusula notwithstanding en la Ley que regula la fórmula de juramento que han de prestar los ciudadanos que adquieren la nacionalidad canadiense, Citizenship Act, para evitar que tal formalismo fuera considerado por los Tribunales contrario a la Carta ${ }^{57}$. Finalmente, la enmienda a la citada Ley no prosperó, aunque por meras razones de considerar el Gobierno que había de estudiarse más detenidamente la propuesta y analizar sus posibles efectos ${ }^{58}$.

Tampoco las Asambleas provinciales han hecho un uso frecuente de las cláusulas. Incluso, existe el ejemplo de la provincia de Manitoba, la cual manifestó desde la aproba-

56 HIEBERT, J.L., «Compromise and the Notwithstanding Clause: why the dominant narrative distorts our understanding», cit., pág. 1. Puede accederse a dicha ponencia a través de la página web de la Canadian Political Science Association, en www.cpsa-acsp. ca.

57 Vid. Bill S-225: «2.1 The provisions of this Act relating to the taking of the oath of citizenship and the form of that oath operate notwithstanding sections 2 and 15 of the Canadian Charter of Rights and Freedoms».

58 Vid. Debates of the Senate (Hansard), 2nd Session, 40th Parliament, vol. 146, iss. 75, December 1, 2009, pág. 1847.

UNED. Teoría y Realidad Constitucional, núm. 30, 2012, pp. 387-409. 
ción de la Carta que no haría uso en el futuro de las cláusulas ${ }^{59}$. La propia doctrina destaca que el debate público y académico acerca de las mismas es prácticamente inexistente, dado el escaso uso de las mismas por parte de los legisladores ${ }^{60}$.

Hogg y Bushell señalan que en la práctica el artículo 33 ha perdido su importancia, ya que se ha desarrollado un clima político de resistencia a su uso. Sólo en Quebec parece políticamente aceptable acudir al mismo ${ }^{61}$. Así, la Asamblea de Quebec es la que ha recurrido con más frecuencia a la fórmula notwithstanding de manera que la mayoría de las leyes que ha aprobado a partir de la entrada en vigor de la Carta de Derechos y Libertades de 1982 han incluido la cláusula ${ }^{62}$. Se trataría, por tanto, de una fórmula que no se habría instituido como un elemento esencial del sistema constitucional canadiense, sino tan sólo como un mero recurso excepcional que se ofrece en relación al principal conflicto que existe en el sistema, que es el estatus de Quebec ${ }^{63}$.

La resistencia política deriva, además, del riesgo político que se asume acudiendo a las cláusulas, de manera que tanto los partidos de la oposición como los medios de información podrían encontrar en su uso un buen argumento para atacar al Gobierno ${ }^{64}$. Como señala Baker, "a government that employs the notwithstanding clause is open to be charge that it has abandoned Chartes values», es decir, ser tildado de "anti-Charter, anti-rights, and even un-Canadian» ${ }^{65}$. Ello, además, se produciría tanto en el caso de que se tratara de salvar normativamente una decisión de inconstitucionalidad como en el caso de que se pretendiera blindar una norma. En este caso, el mero recurso a la cláusula generaría dudas acerca del respeto a la Carta y, por tanto, abriría el camino a la crítica política e, incluso, a la demagogia. En relación con el riesgo político, debe recordarse que según indican las encuestas en Canadá, un enfrentamiento entre los jueces y el Parlamento, no habría de re-

59 FIELD, M.A., «The differing federalism of Canada and the United States», Law and Contemporary Problems, vol. 55, n. ${ }^{\circ} 1$, págs. 107 a 120 . Hemos accedido a dicho trabajo a través del amplio resumen que se recoge en JACKSON, V.C. y TUSHNET, M., Comparative constitutional Law, 2. edición, Foundation PressThomson West, Nueva York, 2006, pág. 939.

60 FRASER, C.A., «Constitutional dialogues between Courts and Legislatures: Can we talk?», en VVAA, Courts and Legislatures: the terms of the discourse, op. cit., pág. 11.

61 HOGG, P. W. y BUSHELL, A.A., «The Charter dialogue between Courts and Legislatures: ...», cit, pág. 83 .

62 Inmediatamente después de que la Carta de Derechos entrara en vigor en 1982, Quebec sancionó una ley ómnibus que añade una cláusula notwithstanding a todos las leyes de la provincia: La Ley relativa a la Ley sobre la Constitución, 1982 (an Act Respecting the Constitution Act). Tal respuesta vino motivada por el hecho de que la Ley fue aprobada sin el consentimiento de Quebec.

63 TUSHNET, M., «Policy distortion and democratic debilitation: ...», cit., p pág. 296.

64 MANDEL, M., The Charter of Rights and the legalization of politics in Canada, Wall \& Thompson, Toronto, 1989, pág. 76; cita tomada de TUSHNET, M., «Policy distortion and democratic debilitation: ...», cit., pág. 283.

65 BAKER, D., Not quite supreme. The Courts and coordinate constitutional interpretation, McGill- Queen's University Press, Montreal, 2010, pág. 44. Y como recuerda SNOW, pese a que el Tribunal Supremo se ha mostrado bastante comedido en la interpretación de la Carta, no han faltado ocasiones en las que determinadas decisiones han provocado un profundo rechazo en el Gobierno y Parlamento, y pese a ello, no se ha acudido a la cláusula. Véanse, casos tales como la anulación de una Ley que prohibía la publicidad del tabaco y exigía que las cajetillas incluyeran advertencias sobre los peligros para la salud (RJR MacDonald Inc. v. Canada (Attorney General, 1998), o un caso sobre pornografía infantil ( $R$. v. Sharpe, 1999). Vid. SNOW, D. «Notwithstanding the override: path dependence, section 33, and the charter», Innovations: a Journal of Politics, vol. 8, año 2008-2009, pág. 4. 
solverse por la opinión pública a favor precisamente de este último ${ }^{66}$. La percepción que tiene el pueblo canadiense es que la Carta ni ha provocado activismo judicial indebido ni ha supuesto un peligro para la democracia ${ }^{67}$.

Esta atrofia institucional en el uso de las cláusulas que viene ya prolongándose en el tiempo va a provocar, a la postre, que cada vez sea más difícil que el Parlamento y las Asambleas puedan recurrir en el futuro a las mismas. La falta de dinamismo permite afirmar, pues, que estas figuras constituyen ya más una ficción que una hazaña de la imaginación constitucional ${ }^{68}$ (the less it is used, the less likely that it will be used) ${ }^{69}$. Sin embargo, también hay autores que consideran que tal aparente renuncia obedece en verdad al self restraint que ha presidido en estos años la actuación de los Tribunales, de manera que si éstos pretendieran asumir un papel políticamente más activo en el ejercicio de sus poderes, las cláusulas cobrarían protagonismo ${ }^{70}$. Se ha apuntado que la propia presencia de las cláusulas jugaría en el sistema constitucional un cierto papel simbólico que actuaría como freno a las pretensiones que pudieran tener los Tribunales de asumir un papel político más activo ${ }^{71}$.

En todo caso, puede afirmarse que si bien el cambio sustancial que provoca la aprobación de la Carta queda mitigado con su artículo 33, en Canadá se ha producido una auténtica transformación de una democracia parlamentaria a una democracia constitucional $^{72}$, aunque en su fórmula de weak judicial review ${ }^{73}$.

Leeson apunta, como causas conjuntas de este desuso de las cláusulas en la realidad político-constitucional, la disciplina de partidos y la expectativa de los altos funcionarios del Gobierno de poder acceder algún día a puestos en la carrera judicial. Ello lo explica el autor del siguiente modo: la disciplina de partido ha determinado que la opinión acerca de las decisiones de los Tribunales quede, no en manos de los miembros del Parla-

66 Según indican las encuestas, los canadienses consideran que los jueces deberían precisamente gozar de más poder. Vid. CHWIALKOWSKA, L., «Poll Shows Canadians Divided on Judges» Power to «Make Law», National Post, edición del 18 de febrero de 2000, pág. A4; citada tomada de LEESON, H., «Section 33, the Notwithstanding Clause: a paper tiger?», op. cit., pág. 18. Igualmente, establecen que el $84 \%$ de los canadienses consideran que la Carta ha sido una buena cosa, mientras que sólo el $4 \%$ la valora negativamente. Además, para el 71\%, los Tribunales, y no el Parlamento, deberían tener la última palabra sobre la interpretación correcta de la Constitución y el $55 \%$ consideró que la Carta ha ayudado a unificar el país. Finalmente, puede destacarse que la Carta encuentra, incluso, más aprobación en la provincia de Quebec que en otras zonas de Canadá. Vid. Encuesta: «The Charter: dividing or uniting Canadians?», CRICS Papers, Centre for Research and Information on Canada, april 2002, pág. 8; referencia tomada de BASTARECHE, M., «La Carta canadiense de los Derechos y de las Libertades y la sociedad canadiense», cit., pág. 21. Puede accederse a dicho trabajo a través de la página web de la Fundación, en www.fundacionmgimenezabad.es. Igualmente, puede accederse a dicha encuesta a través de la página web del en www.ccu-cuc.ca.

67 BASTARECHE, M., «La Carta canadiense de los Derechos y de las Libertades y la sociedad canadiense», cit., pág. 21. Puede accederse a dicho trabajo a través de la página web de la Fundación, en www.fundacionmgimenezabad.es.

68 CAMERON, J., «The Charter's legislative override: feat or figment of the constitutional imagination» en HUSCROFT, G. y BRODIE, I., Constitutionalism in the Charter era, op. cit., págs. 140 a 141.

69 LEESON, H., «Section 33, the Notwithstanding Clause: a paper tiger?», op. cit., pág. 20.

70 Ibidem, pág. 4.

71 Vid. TUSHNET, M., Weak Courts, strong rights: ..., op. cit., pág. 52.

72 KAHANA, T., «Canada», en OLIVER, D. y FUSARO, C. (Edits.), How Constitutions change. A comparative study, Hart, Oxford, 2011, pág. 20.

73 Vid. TUSHNET, M., Weak Courts, strong rights: ..., op. cit., pág. 24. 
mento, sino del Gobierno y, dado que sus altos funcionarios, sobre todo, los del área de Justicia, suelen albergar la esperanza de ocupar algún día alguna posición en la carrera judicial, es habitual que su valoración de las decisiones judiciales sea muy moderada, evitándose posibles conflictos institucionales que desembocaran en el recurso a las cláusulas $^{74}$.

\section{LA EXCEPCIÓN DE QUEBEC Y ALGÚN CASO CONCRETO MÁS}

Como hemos destacado ya antes, la falta de recurso a las cláusulas es predicable del sistema constitucional canadiense en su conjunto, salvo en lo que se refiere a la posición de Quebec. Como ejemplo de la resistencia de Quebec al control de constitucionalidad por parte del Tribunal Supremo en que se traduce el hecho de que en dicha provincia sí haya tenido el recurso a la cláusula alguna, aunque a la postre, mínima virtualidad, puede citarse el caso de la exigencia del uso de la lengua francesa en las actividades comerciales. Así, el gobierno provincial aprobó una serie de normas que exigían que todos los anuncios y carteles comerciales en la provincia, tanto fuera como dentro de los establecimientos comerciales, estuvieran en lengua francesa. Sin embargo, el Tribunal Supremo acordó en dos Sentencias de 1988 (Ford v. Quebec ${ }^{75}$ y Devine v. Quebec) que una prohibición total del empleo de lenguas diferentes al francés constituía una restricción desproporcionada de la libertad de expresión ${ }^{77}$. Frente a tal decisión, la Asamblea de Quebec modificó las normas, limitando la prohibición a los anuncios y carteles exteriores e incorporando una cláusula notwithstanding por la que salvaba dicha legislación por un periodo de cinco años. Posteriormente, dicha cláusula no fue objeto de prórroga, sustituyéndose las normas por otras en la que se permitía utilizar otras lenguas en los anuncios y carteles, tanto en el exterior como en el interior de los establecimientos comerciales, siempre que se empleara el francés.

No ha sido Quebec, en todo caso, la única provincia que ha acudido a las cláusulas, aunque como veremos, se ha tratado de dos casos muy puntuales. Puede destacarse, así, el caso de la provincia de Alberta que recurrió al override power para proteger su Ley sobre matrimonio de 2002 (Marriage Act) frente a una posible declaración de inconstitucionalidad por parte del Tribunal Supremo Federal al amparo del principio de igualdad proclamado en el artículo 15 de la Carta de Derechos y Libertades. En aquella Ley se definía matrimonio al celebrado entre un hombre y una mujer, no aceptándose como tal el ce-

74 LEESON, H., «Section 33, the Notwithstanding Clause: a paper tiger?», op. cit., pág. 18.

75 En el caso Ford se planteo un conflicto legal como consecuencia de que el Sra. Ford empleara en su tienda en la que vendía productos de lana un cartel anunciador que decía «Laine-Wool».

76 El Tribunal Supremo consideró que la prohibición del uso de otras lenguas diferentes a la francesa y, concretamente, de la lengua inglesa no representaba un límite necesario para satisfacer el interés general que representa la promoción y defensa de la cultura y lengua francesa en Quebec. Además, el Tribunal Supremo incluyó dentro de la esfera de protección de la libertad de expresión a la publicidad comercial (commercial speech). En nuestro país, la posición que ha mantenido sobre este última cuestión nuestro Tribunal Constitucional ha sido precisamente la contraria. Así, puede verse la STC 87/1987 y, especialmente, el resumen sobre la doctrina jurisprudencial que se recoge en el Informe del Consejo de Estado de 9-III-2011, sobre anuncios de prostitución en prensa.

77 El artículo 1 establece, literalmente, que «marriage means a marriage between a man and a woman». 
lebrado entre personas del mismo sexo ${ }^{78}$. Sin embargo, finalmente, la inclusión de la cláusula por parte de la Asamblea de Alberta no fue más allá, ya que, por un lado, el Tribunal Supremo declaró que la definición del matrimonio constituye una cuestión que corresponde, en exclusiva, al Estado central, estando fuera de las competencias de los gobiernos provinciales ${ }^{79}$. Por otro lado, las autoridades de la provincia acabaron admitiendo que si el Parlamento nacional aprobaba una Ley nacional sobre matrimonio civil, y la misma incluía dentro del concepto de matrimonio el celebrado entre personas del mismo sexo, no recurriría nuevamente a la cláusula ${ }^{80}$.

También existe otro precedente en la provincia de Saskatchewan, en la que para mantener una norma que pretendía poner fin a una huelga de empleados públicos, se acudió a la cláusula del artículo 33 de la Carta frente a la decisión de la Corte de Apelación de la provincia ( $R W D S U$ v. Saskatchewan, 1985).

En definitiva, vista la evolución de las cláusulas y el escaso recurso a ellas que se ha hecho por los Parlamentos provinciales (incluso alguno, como hemos señalado, ha renunciado expresamente a acudir a las mismas), podemos afirmar que no se trata de una fórmula que, por lo que al caso concreto de Canadá se refiere, anticipe una nueva forma de constitucionalismo o, lo que viene a ser lo mismo, un nuevo reequilibrio entre los poderes y facultades del poder legislativo y el poder contramayoritario. Se trata de un mero instrumento que surge al amparo de los recelos que para la tradición esencialmente británica que presidía el sistema jurídico canadiense suscitaba la aprobación de una Carta de derechos y libertades. El problema parecía radicar más en esta cuestión que en el propio hecho federal. Sin embargo, la evolución de la figura y, sobre todo, el mero hecho de que su uso haya quedado circunscrito al ámbito de Quebec nos permite afirmar también que, en definitiva, se trata ya de una mera fórmula más propia de la asimetría y flexibilidad que muestra la organización territorial canadiense por el problema de Quebec ${ }^{81}$.

\section{1. ¿QUÉ PUEDE ENSEÑARNOS LA EXPERIENCIA CANADIENSE?}

Nuestro Estado se ha incorporado a través de su Constitución de 1978 a una fórmula, muy habitual en la Europa continental tras la Segunda Guerra Mundial, de de-

78 Reference Re Same-Sex Marriage, 2004.

79 El Parlamento nacional aprobó finalmente la Ley sobre matrimonio, Civil Marriage Act, en 2005, en la que se establecía que dentro del concepto de matrimonio podía incluirse el celebrado entre personas del mismo sexo, incluyéndose, además, una exclusión expresa en su Preámbulo del recurso a la cláusula. Vid. JOHANSEN, D. y ROSEN, P., «The notwithstanding clause of the Charter», cit., págs. 12 y 13. Puede accederse a este trabajo a través de la página web del Parlamento canadiense, en www.parl.gc.ca.

80 TUSHNET sitúa el fracaso de la cláusula, en parte, en que solamente ha favorecido determinados regímenes específicos de derechos, sobre todo, en relación al uso de la lengua, en Quebec. Vid. TUSHNET, M., «The rise of weak-form judicial review», en GINSBURG, T. y DIXON, R. (Edits.), Comparative constitutional Law, Edward Elgar, Cheltenham, 2011, pág. 330.

81 Así, por ejemplo, en la Sentencia 45/1989, el Tribunal valoró la constitucionalidad de determinados preceptos de la Ley 44/1978, de 8 de septiembre, de normas reguladoras del Impuesto sobre la Renta de las Personas Físicas, teniendo en cuenta la reforma operada por la Ley 48/1983 (téngase en cuenta también la Sentencia 209/1988, en la que se resuelve, conjuntamente con la estimación del amparo, elevar al Pleno la cuestión de inconstitucionalidad sobre los preceptos discutidos). El debate constitucional se centraba, en concreto, en la exi- 
mocracia constitucional. Incluso, podría afirmarse que dicha fórmula lo ha sido en una versión, empleando la distinción de Tushnet, de strong judicial review, aunque también atemperada a través de determinados elementos, como serían, entre otros, la forma de designación de los miembros del Tribunal Constitucional, el mandato temporal de éstos o la tradicional distinción entre inconstitucionalidad y nulidad que el Tribunal Constitucional ha efectuado al amparo del artículo 39.1 de su Ley Orgánica.

Cierto es, también, que nuestra judicial review será más o menos fuerte, en la medida que nuestro Tribunal Constitucional opte por seguir el camino del denominado judicial activism o, por el contrario, promueva la self restraint. En todo caso, más de treinta años de jurisdicción constitucional permiten afirmar que nuestro Tribunal ha sido habitualmente muy respetuoso con el equilibrio de poderes y con el papel constitucional que se le atribuye tanto al Parlamento como al Gobierno. Así pues, habiéndose instaurado una fórmula formal de control fuerte, el Tribunal ha huido de cualquier activismo político.

Sin embargo, la pretensión de avanzar hacia una fórmula más débil de control constitucional no ha estado ausente en nuestro país, y ello, más allá del mero debate académico. A este respecto, debemos recordar que nuestro legislador pretendió introducir una especie de cláusula, si bien no notwithstanding, sí próxima a una weak-form judicial review, en la última reforma de la Ley Orgánica del Tribunal Constitucional, llevada a cabo por la Ley Orgánica 6/2007. Así, en el artículo 39 se introducía el siguiente texto: «Cuando la sentencia declare la inconstitucionalidad, declarará igualmente la nulidad de los preceptos impugnados o cuestionados. No obstante, motivadamente y para preservar los valores e inte-

gencia de declaración conjunta de determinadas modalidades de unidad familiar. Pues bien, el Tribunal declaró inconstitucionales los preceptos controvertidos, ya que la regulación de la declaración única y conjunta de los esposos imponía a cada uno de ellos el deber de denunciar ante la Hacienda Pública las incorrecciones en que, a su juicio, incurre su respectivo cónyuge en la estimación de sus propias rentas y está obligada manifestación pública de una discordia en el seno de la familia no es tampoco compatible con la intimidad familiar (FJ 9. ${ }^{\circ}$ ). Sin embargo, al entrar a valorar los efectos de tal declaración de inconstitucionalidad y consiguiente nulidad de los preceptos afectados por la misma, el Tribunal, aún admitiendo que en nuestro sistema, a diferencia de otros, no cabe aplazar o diferir los efectos de la declaración de inconstitucionalidad, señala que la vinculación entre inconstitucionalidad y nulidad no «es siempre necesaria, ni los efectos de la nulidad en lo que toca al pasado vienen definidos por la Ley, que deja a este Tribunal la tarea de precisar su alcance en cada caso, dado que la categoría de la nulidad no tiene el mismo contenido en los distintos sectores del ordenamiento». Y en el caso concreto objeto de enjuiciamiento, es al Parlamento a quien ha de corresponder, una vez conocido el tenor de la Sentencia, «llevar a cabo las modificaciones o adaptaciones pertinentes en el régimen legal del impuesto, sirviéndose para ello de su propia libertad de configuración normativa que, como hemos venido señalando, no puede ser ni desconocida ni sustituida por este Tribunal Constitucional». Ciertamente, al Tribunal no le escapaba, buscando quizás más la razonabilidad que la racionalidad, que los efectos retroactivos de tal declaración suponían un evidente desajuste del Presupuesto del Estado. Por ello, acude a una modalidad de cláusula notwithstanding que permite atenuar las consecuencias del control de constitucionalidad. Posteriormente, el Tribunal Constitucional ha vuelto a recurrir a la distinción entre inconstitucionalidad y nulidad en su Sentencia 236/2007, relativa a la Ley Orgánica 8/2000, de 22 de diciembre, de reforma de la Ley Orgánica 4/2000, de 11 de enero, sobre Derechos y Libertades de los Extranjeros en España y su Integración Social. Vuelve a declarar en este caso el Tribunal que no corresponde a este Tribunal decidir una determinada opción en materia de extranjería, ya que su pronunciamiento debe limitarse, en todo caso, a declarar si tiene o no cabida en nuestra Constitución aquélla que se somete a su enjuiciamiento. De ahí que la inconstitucionalidad apreciada exija que sea el legislador, dentro de la libertad de configuración normativa derivada de su posición constitucional y, en última instancia, de su específica libertad democrática, el que establezca dentro de un plazo de tiempo razonable las condiciones de ejercicio de los derechos de reunión, asociación y sindicación por parte de los extranjeros que carecen de la correspondiente autorización de estancia o residencia en España. 
reses que la Constitución tutela, la sentencia podrá declarar únicamente la inconstitucionalidad o diferir los efectos de la nulidad por un plazo que en ningún caso será superior a tres años». Obviamente, se trataría, como hemos dicho, de una modalidad blanda de cláusula en la medida que se limita a diferir los efectos de la sentencia y que la decisión no corresponde al poder legislativo, sino al propio Tribunal Constitucional. En todo caso, dicho texto no quedó finalmente incorporado a la Ley Orgánica 6/2007.

Más recientemente, y en previsión de que por el Tribunal Constitucional se declararan inconstitucionales diversos preceptos de la Ley Orgánica 6/2006, de 19 de julio, por la que se aprobó la reforma del Estatuto de Cataluña, en el Senado se presentó por los Grupos Parlamentarios Entesa Catalana de Progrés y Catalán en el Senado de Convergència i Unió, una Proposición de Ley Orgánica de modificación de la Ley Orgánica 2/1979, de 3 de octubre, del Tribunal Constitucional ${ }^{82}$. Dicha proposición de reforma de la Ley Orgánica del Tribunal Constitucional recogía, entre otras propuestas, la pretensión de introducir una limitación a los poderes revisores del Tribunal en materia de configuración del modelo autonómico. A este respecto, la Exposición de Motivos de la precitada proposición de reforma dispone, literalmente, que «en la medida que la función constitucional que tiene asignada el Estatuto (de Autonomía) se relaciona directamente con el poder Constituyente, y en tanto que esta función vincula a "todos los poderes públicos », habría que sostener que el Tribunal Constitucional también debería estar sometido a este principio de «ingerencia limitada» en la función del Constituyente». De este modo, la pretensión de sus proponentes no es otra que la de dificultar que por obra del control de constitucionalidad que corresponde al Tribunal Constitucional se pueda por éste declarar la inconstitucionalidad total o parcial de los Estatutos de Autonomía y, en especial, de los que han sido aprobados en referéndum. Como ponía de manifiesto la Exposición de Motivos: "las normas que emanan de poderes legítimos disfrutan de una presunción de legitimidad y esta presunción es, además, tanto más enérgica cuanto más directa es la conexión del órgano con la voluntad popular y llega por eso a su grado máximo en el caso del legislador, que lo es, precisamente, por ser el representante de tal voluntad. Los Estatutos de Autonomía, que han sido aprobados por mayorías reforzadas en un Parlamento autonómico y por mayoría absoluta en las Cortes Generales, cuentan con una doblemente reforzada presunción de legitimidad que además en algunos casos se manifiesta directamente mediante su aprobación en referéndum».

Los mecanismos que pretendían introducirse a través de dicha propuesta de reforma para dificultar la declaración de inconstitucionalidad de los Estatutos de Autonomía aprobados por medio de referéndum eran dos: por un lado, una limitación del lapso temporal con el que cuenta el Tribunal Constitucional para poder pronunciarse al respecto de seis meses. En el caso de que el Tribunal no se hubiera pronunciado dentro de dicho plazo, se entenderá desestimado el correspondiente recurso; y, por el otro, se establece un régimen especial de mayorías dentro del propio Pleno de manera que la declaración de inconstitucionalidad total o parcial del correspondiente Estatuto exigirá una mayoría de ocho de los doce miembros del Tribunal.

Además, la misma propuesta de reforma impedía que en el control de la constitucionalidad de los Estatutos de Autonomía pudiera recurrirse a las sentencias interpreta-

82 Vid. BOCG de 27-V-2010.

UNED. Teoría y Realidad Constitucional, núm. 30, 2012, pp. 387-409. 
tivas, debiendo circunscribirse el pronunciamiento a la declaración de su conformidad o disconformidad con la Constitución Española.

Como puede verse, el debate acerca de la conveniencia debilitar el poder revisor que ostenta el Tribunal Constitucional, pese a que quede, en muchas ocasiones, enmarcado dentro de la discusión entre democracia parlamentaria y democracia constitucional, a la postre, trae su razón política de ser, como finalmente ha ocurrido en la experiencia canadiense, en las tendencias centrífugas de algunos partidos políticos de naturaleza nacionalista. Parece que las ataduras de Ulises son ahora molestas, no desde la perspectiva de la democracia o del principio mayoritario, sino desde la perspectiva de los nacionalismos y ego territorialismos.

Resulta interesante resaltar que la controversia acerca del poder contra-mayoritario se sitúa no ya en sede de la división de poderes, en la medida que la interpretación de la Constitución estuviera en manos de un Tribunal Constitucional o en manos del Parlamento que encarna la voluntad popular, sino en sede de la organización territorial del Estado. En efecto, fuera del marco iusfilosófico que enfrenta constitucionalismo y democracia, el debate en el Derecho constitucional va ceñido a los problemas que la interpretación de la Constitución en manos del poder contra-mayoritario conlleva para las pretensiones descentralizadoras de determinadas comunidades regionales o federales. Como hemos visto, el caso de Canadá es paradigmático, ya que el debate se circunscribe al hecho territorial y a la tendencia centralizadora que históricamente se ha presumido del poder contra-mayoritario (véase, a este respecto, el ejemplo del Tribunal Supremo de los Estados Unidos de América a través, fundamentalmente, de la doctrina de los poderes implícitos y, en concreto, de la commerce clause).

Ciertamente el debate afecta también a la clásica división de poderes, porque lo que se pone en discusión es el poder, no del Parlamento territorial, para extender la descentralización sin socavar el texto constitucional, sino del propio Parlamento nacional que ha aceptado las demandas de las fuerzas regionales que aspiran a un mayor grado de autogobierno. Sin embargo, el epicentro del mismo se ha alterado lo que exigiría una reflexión que conectara ambos hechos, ya que ahora no se pretende salvar directamente el poder del Parlamento, sino la satisfacción de las pretensiones de determinados intereses territoriales ¿Es entonces el mismo debate? Ciertamente la contestación a dicha cuestión excede con creces del objeto de este trabajo, pero no por ello debemos dejar de apuntar tal extremo, porque, en muchas ocasiones, seguimos planteando viejos discursos bajo postulados que se han visto superados por el contexto histórico-político en el que se presentan ${ }^{83}$.

\section{CONCLUSIONES}

Podemos ya contestar a la pregunta con la que iniciábamos nuestro trabajo, ¿vuelven las sirenas?

83 A este respecto, GARCÍA MARTÍNEZ apunta con acierto que el problema real de la legitimidad de la justicia constitucional se suscita en los procesos constitucionales en los que la dimensión política es evidente e inmediata, es decir, prácticamente en los procesos de control de constitucionalidad y de conflictos de competencia GARCÍA MARTÍNEZ, M.A., «El Tribunal Constitucional. De la legitimidad de origen a la legitimidad de ejercicio», Revista Parlamentaria de la Asamblea de Madrid, núm. 21, diciembre 2009, pág. 124. 
Pues bien, la experiencia canadiense demuestra, a través de la evolución de las cláusulas notwithstanding y override incorporadas al artículo 33 de la Carta de Derechos y Libertades, como instrumento que atemperara en cierto modo el poder que dicha norma constitucional venía a atribuir a los Tribunales, que, al menos, en el plano político-constitucional, la democracia constitucional parece mostrarse bien atada, sin que se escuchen muchos cantos de sirenas. A este respecto, debemos recordar que las citadas cláusulas surgen al amparo del debate entre democracia parlamentaria y democracia constitucional que suscitó la aprobación de la Carta y también de la pretensión de que quedaran garantizadas ciertos hechos diferenciales que podían presumirse en una organización descentralizada singular como la canadiense.

Sin embargo, tras treinta años de la aprobación de la Carta y de plena incorporación al sistema constitucional canadiense de las cláusulas, puede afirmarse que el debate entre el poder mayoritario y contramayoritario que las presidió parece haber cesado. Incluso, la posición que mantienen al respecto los ciudadanos canadienses aboga, no sólo, por mantener, sino por avanzar en la democracia constitucional. El pueblo canadiense ha primado el lado positivo que ofrece la Carta, en el sentido de constituir una garantía para los derechos y libertades, tanto de las minorías, muy presentes en Canadá, como de todos los ciudadanos frente a los abusos que en ocasiones comete la mayoría.

Ello, en parte, ha sido posible por la propia actitud de respeto que ha mostrado el Tribunal Supremo canadiense hacia una tradición jurídica fundada en la supremacía del Parlamento. Pero tampoco podemos olvidar que durante estos treinta años la voz del Tribunal ha tenido que alzarse, esgrimiendo la Carta, para recordarle al Parlamento que por encima de su voluntad se encuentran, en muchas ocasiones, los derechos y libertades de las personas y el respeto al principio de proporcionalidad. Es decir, dicho respeto no ha sido, como nos ilustra la doctrina canadiense, ni sumisión ni rechazo al poder que le otorga la Carta.

De este modo, el único debate que parece dar ya sentido a las cláusulas es el del hecho diferencial que supone la posición que ocupa en el sistema constitucional la provincia de Quebec.

Tal experiencia nos permite afirmar, como hacíamos al final del apartado anterior, que el debate acerca de la conveniencia de debilitar o no al poder revisor del Tribunal Constitucional, ya no se presenta en la realidad político-constitucional como un planteamiento entre democracia parlamentaria frente a democracia constitucional, sino como la mera pretensión de que el principio de igualdad en los derechos y libertados quede difuminado por un mero hecho territorial diferencial.

RESUMEN: Tras la Segunda Guerra Mundial, el modelo de democracia constitucional, en virtud del cual, la última palabra acerca de la constitucionalidad de las leyes no podrá recaer ya en el Parlamento, sino en el denominado poder contramayoritario, se ha impuesto en gran parte de los Estados constitucionales, no sólo de Europa, sino del resto del mundo. Incluso, Estados tradicionalmente basados en el principio de supremacía del Parlamento se han visto arrastrados por dicha tendencia, en gran parte por la repercusión que internacionalmente ha tenido el Convenio Europeo y su Tribunal, y así, al am- 
paro de la aprobación de las correspondientes Cartas de Derechos y Libertades, han otorgado a los Tribunales de Justicia la facultad de controlar las leyes del Parlamento. Así pues, puede afirmarse que el viejo modelo de la judicial review que se iniciara a comienzos del siglo XIX en Estados Unidos, parece haber triunfado, con versiones más o menos corregidas del mismo. Tal paradigma, sin embargo, encuentra algunas excepciones aún e, incluso, está siendo objeto de revisión, postulándose, no ya, un retorno a la supremacía del legislador, pero sí al menos el desarrollo de fórmulas débiles de control de constitucionalidad (weak-form judicial review). El ejemplo más característico de estas formas débiles lo encontramos en el sistema constitucional canadiense a través de las cláusulas notwithstanding y override que incorpora la Carta de Derechos. Su origen y, en mayor manera, su evolución pueden ser una interesante experiencia para nuestro propio sistema constitucional.

TITLE: The notwithstanding and override clauses in the Canadian constitutional system

ABSTRACT: After World War II, the model of constitutional democracy, under which, the last word on the constitutionality of laws can't be decided by the Parliament, but by the countermajoritarian power, has prevailed in much of the constitutional States. It has happened not only in Europe, also around the World. Even, States traditionally based on the principle of supremacy of Parliament have been drawn by this trend, perhaps by the international impact of the European Convention and its Court. So, under the approval of the Charters of rights and Freedoms, they have given the courts the power to control acts of Parliament. Therefore it can be argued that the old model of judicial review that began in the early nineteenth century in US seems to have succeeded, with more or less corrected versions of it. This paradigm, however, still finds some exceptions, and even is being reviewed, postulating, not a return to the supremacy of the legislature, but at least the development of weak forms of judicial review. The most characteristic example of these weak forms can be found in the Canadian constitutional system through the notwithstanding and override clauses which the Charter of Rights incorporates. Its origin and, more so, its evolution can be an interesting experience for our own constitutional system

Resumen: Tras la Segunda Guerra Mundial, el modelo de democracia constitucional, en virtud del cual, la última palabra acerca de la constitucionalidad de las leyes no podrá recaer ya en el Parlamento, sino en el denominado poder contramayoritario, se ha impuesto en gran parte de los Estados constitucionales, no sólo de Europa, sino del resto del mundo. Incluso, Estados tradicionalmente basados en el principio de supremacía del Parlamento se han visto arrastrados por dicha tendencia, en gran parte por la repercusión que internacionalmente ha tenido el Convenio Europeo y su Tribunal, y así, al amparo de la aprobación de las correspondientes Cartas de Derechos y Libertades, han otorgado a los Tribunales de Justicia la facultad de controlar las leyes del Parlamento. Asípues, puede afirmarse que el viejo modelo de la judicial review que se iniciara a comienzos del siglo XIX en Estados Unidos, parece haber triunfado, con versiones más o menos corregidas del mismo. Tal paradigma, sin embargo, encuentra algunas excepciones aún e, incluso, está siendo objeto de revisión, postulándose, no ya, un retorno a la supremacía del legislador, pero sí al menos el desarrollo de fórmulas débiles de control de constitucionalidad (weak-form judicial review). El ejemplo más característico de estas formas débiles lo encontramos en el sistema constitucional canadiense a través de las cláusulas notwithstanding y override que incorpora la Carta de Derechos. Su origen y, en mayor manera, su evolución pueden ser una interesante experiencia para nuestro propio sistema constitucional.

KeY Words: Democracy. Constitutionalism, Judicial review, Comparative Constitutional Law. Canada. Charter of Rights and Freedoms. Supremacy of Parliament

Palabras Clave: Democracia. Constitucionalismo Control de constitucionalidad. Derecho constitucional comparado. Canadá. Carta de Derechos y Libertades. Supremacía del Parlamento

FECHA DE RECEPCIÓN: 05.04.2012. FECHA DE ACEPTACIÓN: 19.07.2012 